BMJ Paediatrics Open

\title{
Hitting children is wrong
}

Tony Waterston (D) ,' Staffan Janson ${ }^{2}$

To cite: Waterston T, Janson S. Hitting children is wrong. BMJ Paediatrics Open 2020;4:e000675. doi:10.1136/ bm.jpo-2020-000675

- Additional material is published online only. To view, please visit the journal online (http://dx.doi.org/10.1136/ bmjpo-2020-000675).

Received 18 May 2020 Revised 10 June 2020 Accepted 10 June 2020
Check for updates

\section{(c) Author(s) (or their} employer(s)) 2020. Re-use permitted under CC BY-NC. No commercial re-use. See rights and permissions. Published by BMJ.

${ }^{1}$ Institute of Health and Society, Newcastle University, Newcastle upon Tyne, UK

${ }^{2}$ Public Health, Karlstad University, Karlstad, Sweden

Correspondence to Dr Tony Waterston; tony. waterston@newcastle.ac.uk

\section{INTRODUCTION}

The news ${ }^{1}$ that in April 2020 Japan has become the 59th country to ban corporal punishment in the home highlights the significant progress that is being made to ensure that children receive the same protection as adults against violence. Sweden was the first country to introduce a ban in 1979 followed mainly by countries in northern Europe. At the shift of the millennium, still only 11 countries had introduced a ban, but since then there has been a steady increase, now with bans in all continents.

To many, it seems that the time cannot come quickly enough when we shall look back on smacking children as a remnant of a bygone age as we do on capital punishment. But to some (including many in the UK, and perhaps a majority in African countries, and some parts of the USA), the very thought of a ban is anathema, conjuring up the prospects of the state in the form of police and social workers interfering with the wish of parents to bring up their children in the way that they think is right.

In this article, we review the rationale for the ban and progress with the ban globally, examine the case being made in countries which oppose a ban, assess the evidence from Sweden over its effectiveness and call for renewed action to end the corporal punishment of children.

Most people understand that severe maltreatment is detrimental to children's health and development. Many adults (and even child professionals), on the other hand, still look on corporal punishment as a reasonable chastisement without any negative side effects. From a research point of view, there have been many difficulties in attempts to isolate corporal punishment from more severe forms of maltreatment and a number of other confounding factors. Research during the last 20 years has however shown that corporal punishment itself is associated with an increased probability of adverse physical, mental and behavioural outcomes. Moreover, there are no studies indicating that hitting a child, as a means of discipline, is beneficial for the child. ${ }^{2}$ Finally, the United Nations Convention on the Rights of the Child ${ }^{3}$ article 19 states that it is the right of the child to grow up in an environment free from any form of maltreatment and be looked on as active citizens who can make decisions about their best interest. Children's participation in the field of maltreatment is recently well discussed by Kosher and Ben-Arieh. ${ }^{4}$

\section{GLOBAL PICTURE}

According to the Global Initiative to End all Corporal Punishment of Children, ${ }^{5}$ there are now 59 countries which have full prohibition of corporal punishment in all settings. Japan (as mentioned above) became the 59th such country in March 2020. Twenty-seven EU countries have instituted a ban which represents a large majority of the region. Twentynine more countries have signified their intention to reform their laws in the same direction. Most of Europe and South and Central America have instituted a ban but there are significant gaps around the world, notably in Africa, Asia, Australia, the USA and Russia. The picture in the UK is interesting in that two of the devolved governmentsScotland and Wales-have legalised a ban but England and Northern Ireland have not, despite a number of attempts to pass the necessary legislation. Five countries in Africa together with Saudi Arabia, Pakistan and Malaysia do not yet have full prohibition in any setting. However, there are now seven African countries that have instituted legal prohibition.Table 1 shows a timeline of the countries which have instituted a ban on corporal punishment in the home.

\section{WHY SOME COUNTRIES OPPOSE A BAN}

It is important to recognise that there are still very strongly held views supporting corporal punishment in the home and opposing a state ban, particularly among some religions and cultural groups. This is still the case in England where the tabloid press tends to defend parents for using physical methods 


\begin{tabular}{|c|c|}
\hline 2020 & Japan \\
\hline 2019 & Georgia, South Africa, France, Republic of Kosovo \\
\hline 2018 & Nepal \\
\hline 2017 & Lithuania \\
\hline 2016 & Mongolia, Montenegro, Paraguay, Slovenia \\
\hline 2015 & Benin, Ireland, Peru \\
\hline 2014 & $\begin{array}{l}\text { Andorra, Estonia, Nicaragua, San Marino, Argentina, } \\
\text { Bolivia, Brazil, Malta }\end{array}$ \\
\hline 2013 & Cabo Verde, Honduras, North Macedonia \\
\hline 2011 & South Sudan \\
\hline 2010 & Albania, Congo (Republic of), Kenya, Tunisia, Poland \\
\hline 2008 & $\begin{array}{l}\text { Liechtenstein, Luxembourg, Republic of Moldova, } \\
\text { Costa Rica }\end{array}$ \\
\hline 2007 & $\begin{array}{l}\text { Togo, Spain, Venezuela, Uruguay, Portugal, New } \\
\text { Zealand, The Netherlands }\end{array}$ \\
\hline 2006 & Greece \\
\hline 2005 & Hungary \\
\hline 2004 & Romania, Ukraine \\
\hline 2003 & Iceland \\
\hline 2002 & Turkmenistan \\
\hline 2000 & Germany, Israel, Bulgaria \\
\hline 1999 & Croatia \\
\hline 1998 & Latvia \\
\hline 1997 & Denmark \\
\hline 1994 & Cyprus \\
\hline 1989 & Austria \\
\hline 1987 & Norway \\
\hline 1983 & Finland \\
\hline 1979 & Sweden \\
\hline
\end{tabular}

From The Global Initiative to End all Corporal Punishment of Children. ${ }^{5}$

and attacks the 'nanny state' which seeks to interfere with long hallowed methods of discipline. Opposition to legislation is particularly strong in African countries.

\section{HAS THE BAN WORKED?}

Sweden is the only country that has been able to follow the effect of the ban with repeated studies using the same methodology over a 40-year period. Nationally representative samples of parents have been asked about knowledge, attitudes to spanking and behaviour according to Conflict Tactic Scale, an internationally well renowned methodology developed by Murray Straus ${ }^{6}$ in 1971. Two years after the ban, $>90 \%$ of Swedish adults were aware of the law. While $90 \%$ of parents in Sweden spanked their children in the $1970 \mathrm{~s},<10 \%$ did so in 2000 , and even less in the last survey in 2016. For the majority of young Swedish parents, spanking is not an option and is looked on as adverse behaviour. ${ }^{7}$ There are probably

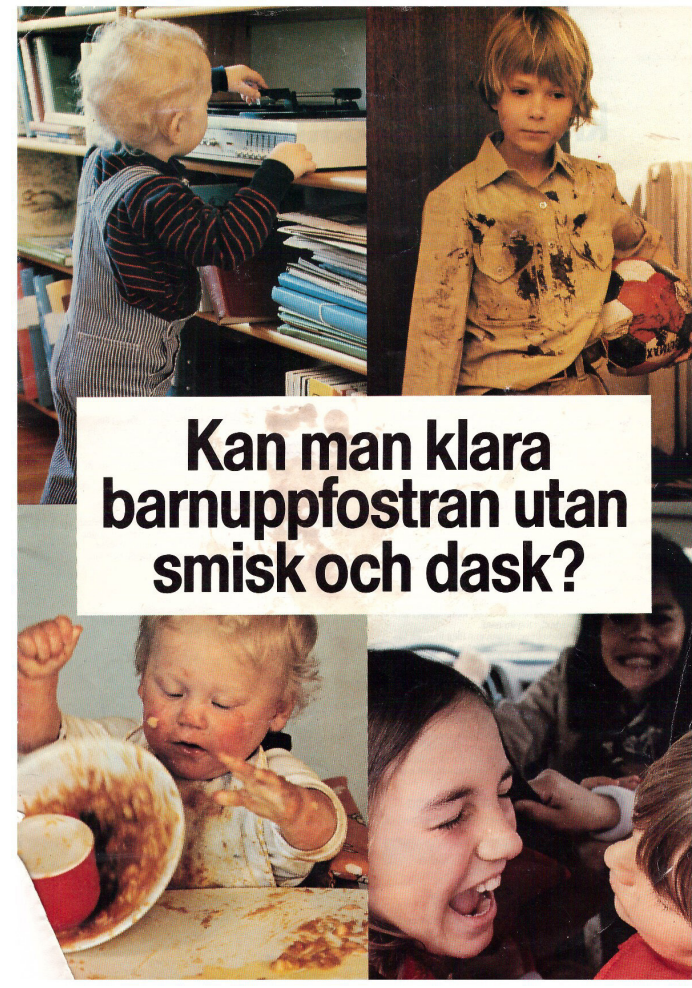

Figure 1 Publicity leaflet Swedish: Can you bring up children successfully without smacking of spanking?

many reasons behind this positive outcome including early political consensus, a welfare state and a comparatively well-educated population.

\section{CHANGING PARENTAL VIEWPOINTS}

Sweden also launched an unprecedented publicity campaign at the time of the introduction of the law (see figures 1 and 2 illustrating the publicity used at the time). Recent research indicates that such campaigns and follow-ups of the law are important as people in many countries continue to believe in the necessity of corporal punishment despite legal bans. ${ }^{8}$ Accordingly, there is a need of follow-up of the effect of the laws in different countries, taken into consideration social inequalities in family attitudes; there is also a need for continuing campaigns and education about the adverse effects of corporal punishment.

\section{A CALL FOR RENEWED ADVOCACY}

It is clear that a considerable amount of education is needed in certain countries to inform the population of the following: that hitting children may stop the behaviour in the short term but in the long term has serious consequences; that if hitting children lightly does not work, parents go on to hit harder and most importantly, that children model their parents' behaviour and if physical violence is the norm to induce prosocial behaviour, then they will learn to use violence themselves as older children and adults. However, it is also critical for 


\section{Can You Bring Up Children Successfully without Smacking and Spanking?}

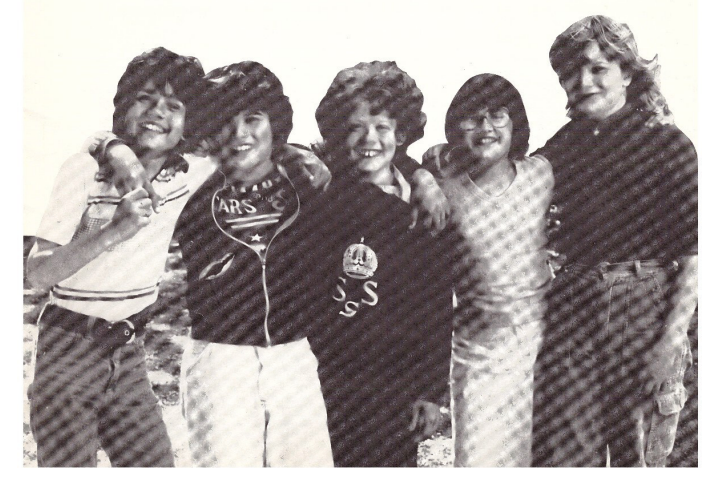

Figure 2 Publicity leaflet English.

the state and local community groups to provide full support and education for parents in tackling difficult child behaviour, which is perhaps worsened by lifestyle (notably family breakup, drug abuse and the excessive use of social media).

In many countries that have instituted a ban, this has come about from consistent and persistent advocacy by professional organisations including paediatricians and children's sector groups working together in a coalition. In Scotland, a group of non-governmental organisations (NGOs) published a report ${ }^{9}$ in 2015 and the Scottish Green Party took the Bill through the Scottish Parliament; there was strong and consistent support from paediatricians in Scotland and from the Royal College of Paediatrics and Child Health. ${ }^{10}$

In countries yet to institute a ban, civil society is also working together and this collaboration gives hope for future reform. For example, in Uganda- a country where there is quite strong support for smacking in the home, the Uganda Child Rights NGO Network ${ }^{11}$ is a coalition of 150 child-focused organisations including community-based, national and international NGOs working for the welfare and rights of children in Uganda which has called for the end to violence against children in the home.

We call on paediatricians and child health professionals around the world to join with others in the children's sector to press their government to take the necessary steps to protect children from all forms of violence. This will require an extensive education campaign both on the high risks of hitting children and on the substantial benefits of non-violent parenting. Practical steps which can be taken by paediatricians are:

- Talk to parents about parenting without violence, its benefits and techniques.

- Make contact with local and global advocacy organisations such as International Society for Prevention of Child Abuse and Neglect, Save the Children, End Corporal Punishment of Children

- Find out your national paediatric association stance on corporal punishment and work with others to influence this

- Write to your MP or other government representative to ask for national legislation against corporal punishment, possibly with anonymised examples from your practice.

Contributors Both authors contributed equally to this editorial.

Funding The authors have not declared a specific grant for this research from any funding agency in the public, commercial or not-for-profit sectors.

Competing interests None declared.

Patient and public involvement Patients and/or the public were not involved in the design, conduct, reporting or dissemination plans of this research.

Patient consent for publication Not required.

Provenance and peer review Commissioned; externally peer reviewed.

Open access This is an open access article distributed in accordance with the Creative Commons Attribution Non Commercial (CC BY-NC 4.0) license, which permits others to distribute, remix, adapt, build upon this work non-commercially, and license their derivative works on different terms, provided the original work is properly cited, appropriate credit is given, any changes made indicated, and the use is non-commercial. See: http://creativecommons.org/licenses/by-nc/4.0/.

ORCID iD

Tony Waterston http://orcid.org/0000-0001-7829-6831

\section{REFERENCES}

1 Japan prohibits all corporal punishment of children. Available: https://endcorporalpunishment.org/japan-prohibits-all-corporalpunishment/

2 Grogan-Kaylor A, Ma J, Graham-Bermann SA. The case against physical punishment. Curr Opin Psychol 2018;19:22-7.

3 Convention on the rights of the child. Available: https://www.unicef. org/child-rights-convention

4 Kosher H, Ben-Arieh A. Children's participation: a new role for children in the field of child maltreatment. Child Abuse Negl 2020:104429 https://doi.org/

5 Global progress. Available: https://endcorporalpunishment.org/ countdown/

6 Straus MA. Some social antecedents of physical punishment: a linkage theory interpretation. J Marriage Fam 1971;33:658-63.

7 Janson S. The development of social and legal aspects of corporal punishment - a Swedish paediatrician's commentary. In: Saunders BJ, Leviner P, Naylor B, eds. Corporal punishment of children comparative legal and and social developments towards prohibition and beyond. Boston: Brill - Nijhoff, 2019.

8 Lansford JE, Cappa C, Putnick DL, et al. Change over time in parents' beliefs about and reported use of corporal punishment in eight countries with and without legal bans. Child Abuse Negl 2017;71:44-55.

9 Equally protected? A review of the evidence on the physical punishment of children. Available: https://learning.nspcc.org.uk/ media/1117/equally-protected.pdf

10 Children (Equal Protection from Assault) (Scotland) Bill. Available: https://www.rcpch.ac.uk/sites/default/files/2018-09/ children_equal_protection_from_assault_scotland_bill_the_scottish_ parliament.pdf

11 Uganda child rights NGO network. Available: https://www.endviolence.org/members/uganda-child-rights-ngo-network 